\title{
Inés Quintero. La palabra ignorada. La mujer: testigo oculto de la historia de Venezuela. Caracas: Editorial Planeta Venezuela, 2016.
}

DOI: http://dx.doi.org/10.15648/hc.33.2018.13

Siendo la segunda mujer en ocupar el cargo de directora en la Academia Nacional de la Historia, Inés Quintero continúa sus obras caracterizadas por estudiar actores y acontecimientos de la época colonial y el periodo independentista, esta vez toma en consideración su género para así publicar su nueva obra titulada La palabra ignorada. La mujer: testigo oculto de la bistoria de Venezuela, en la cual desarrolla la vida de algunas mujeres de varios estratos sociales que fueron parte de nuestra historia y que los estudios históricos tradicionales han dejado un tanto en el olvido.

La historiografía venezolano hasta mediados del siglo XX estuvo caracterizada por tener estándares un tanto machista, esto argumentado a que los hitos históricos estuvieron coordinados y ejecutados por hombres, por ello en la conciencia histórica siempre el papel protagónico estuvo caracterizado por "él", solo en casos excepcionales "ella".

Aunque esta condición parece ser despectiva y hasta cuestionable se debe tomar en cuenta un conjunto de factores que caracteriza la historia de Venezuela, puesto que una de las particularidades de las naciones americanas fue que estuvieron determinadas a las costumbres de los reinos europeos, posterior a los viajes de exploración. La península ibérica conquista y urbaniza la región geográfica que hoy conocemos como Venezuela y a su vez implanta un conjunto de costumbres, esta tradición se caracteriza en colocar al hombre como centro y protagonista de los procesos políticos, económicos y sociales devengando los quehaceres del hogar a las mujeres, esto va a permanecer como una costumbre con el transcurrir del tiempo, hasta la Liberación Femenina que va a implantar la igualdad de género. 
No obstante, hay un dicho que en la jerga popular dice que detrás de un gran hombre hay una gran mujer, y esto sin lugar a dudas lo ha sabido manejar la autora del libro, ya que centra un par de sus historias en la vida personal de dos presidentes de nuestro país. Dominga de Ortiz, una mujer que se comprometió a muy temprana edad con quien para el momento era un peón de hatos, sin darse cuenta de que aquel hombre se llevaría el mérito de instaurar la República y a su vez ser su presidente por varios años. Son muchas las historias que se tejen y que se exaltan al centauro de los llanos, José Antonio Páez, pero muy pocas del destino que tomaría su vida sin la intervención oportuna de su esposa. Dominga fue su esposa en sacramento hasta el último aliento de Páez, sin embargo este matrimonio en hecho duró relativamente poco, puesto que él establece una relación extramatrimonial con Bárbara Nieves dejándola sola al cuidado de sus hijos, a pesar de ello el amor y la devoción permanecieron siempre fieles a su esposo. Una mujer de gran temperamento, imponente y que hacia valer sus derechos la autora explica que son muchas las amarguras, las vergüenzas y los aprietos que tuvo que pasar, precisamente esta convicción nunca la abandonó ni le dio la espalda.

Quien no corrió con tantos males fue la señora Ana Teresa Ibarra, quien contrae nupcias con el amigo de confianza del presidente Juan Crisóstomo Falcón y quien posteriormente lo suplirá en el cargo. Aunque la autora la presenta como una mujer tranquila, sumisa y quien profesara un amor infinito por su cónyuge, tuvo que lidiar con tres grandes dificultades al ser esposa de un presidente: primero el tormento de vivir bajo su ausencia en aquellos viajes diplomáticos que la desvelaba y angustiaba al no tener a su amado consigo, segundo los celos desenfrenados de su consorte quien la mantenía bajo estricta vigilancia y recomendaciones que más que consejos eran exigencias que debía cumplir al pie de la letra para evitar poner el nombre de su amado en inapropiados comentarios públicos y tercero las tensiones políticas suscitadas en el país antes, durante y posterior a su permanencia en el poder.

Si bien es importante resaltar las figuras de estas valiosas mujeres que quizás a través de sus dotes logrando persuadir las decisiones de sus esposos, ellas tuvieron una vida relativamente cómoda debido al estrato social al 
cual pertenecieron. Por ello, Inés Quintero saca a la luz la figura de esas protagonistas dejadas en el olvido resaltando las grandes luchas que diversas mujeres tuvieron que enfrentar para así hacer valer sus derechos como damas y como seres humanos con igualdad de condiciones, algunas como lo relata la autora lograron exponer las injusticias que se le habían condenado, otras no corrieron con la misma suerte y tuvieron que enfrentar el grueso de la inequidad.

La autora narra con un toque de feminismo cómo en la Colonia las mujeres esclavas podían obtener su libertad, expone el caso de dos esclavas que intentaron por las vías legales adquirir esta condición tanto de ella como de sus hijos, claro una de las complicaciones era el tiempo que se ocupaba para conseguir el dinero para comprar su libertad, en uno de los casos la esclava logró conseguir su libertad a través de su compra colocando a cambio años de trabajo para adquirirla y así poder pasar los pocos años de vejez en libertad, la otra esclava no contó con la misma suerte al realiza un trueque con su amo, pactó cambiar su libertad por ocho hijos de su vientre un acto que para muchos sería egoísta pero que cuando la única condición que conoce es la esclavitud es una opción tentadora, lamentablemente en este caso la desdichada no contó con la misma suerte y fue engañada como muchas otras de la época que desearon cambiar lo que se le ofreciera a cambio de su libertad.

Otro caso de total injusticia condena la escritora es el caso de una mulata a la cual el esposo le propinó una paliza que casi le cuesta la vida, pero al investigar el desenlace de la historia la autora queda muy decepcionada cuando al revisar la denuncia impuesta por la desdichada, los alegatos, testigos y las pruebas se determinó que la tunda propinada fue un acto de reprender a su esposa justificando la actitud del esposo y a su vez se alega los celos como causa, un caso que sin lugar a dudas la autora reprocha y puede ser preciso llegar a la conclusión de que en este caso se tapa la realidad para encubrir los actos consumados por un hombre por el simple hecho de ser el sexo dominante de la sociedad.

Como estas, son muchas las historias que han pasado en el olvido y que no se han divulgado, son anécdotas que permanecen en silencio y que lo 
seguirán hasta que el enfoque de la historia comience a cambiar de paradigma y evite mantener las líneas de investigación heredadas a través del tiempo, aunque hay que traer a colación que a partir de la segunda mitad del siglo XX esto ha ido cambiando, varios historiadores se han ocupado en estudiar estos casos, pero aún no es suficiente. Por ello esta obra rinde tributo a todas esas mujeres que han sufrido en silencio todos los designios que una sociedad masculinizada ha desarrollado y a su vez rompe el silencio de aquellos testigos ocultos de la historia de Venezuela.

\section{Yolimar Gil Amundarain}

Universidad Católica Andrés Bello Cursante de la Maestría de Historia de Venezuela yolimar.gil.amundarain@gmail.com 